Mieczysław C. Paczkowski OFM

Nicolaus Copernicus University, Toruń

celestynp@op.pl

ORCID: 0000-0002-4045-2314

DOI: http://dx.doi.org/10.12775/BPTH.2019.025
Biblica

et

Patristica

Thoruniensia

12 (2019) 4: 469-495

ISSN (print) 1689-5150

ISSN (online) 2450-7059

\title{
Isaiah 56:7 in the Patristic Interpretation
}

\section{Iz 56:7 w interpretacji patrystycznej}

\begin{abstract}
The article presents a reflection of the ancient Church based on Isa 56:7. In itself, the theological and spiritual significance of this Isaianic verse can be developed in various ways. In early Christian interpretation, the material of Isaiah served several different ends. Isaiah's concepts and terms become integral to Christian reflection, worship, literature and iconography. The early Church's doctrine of the "house of prayer" included the elements of rejection and hope towards the Jewish people. It is, therefore, rather surprising that it did not exercise any strong impact on the Fathers of the Church. Indeed, the passage of Isaiah is almost neglected as are the NT passages in which it is quoted (Matt 21:13; Mark 11:17). Thus, it was necessary to supplement the reflections on Isa 56:7 with a broader treatment of the ecclesiological strands in the reflection of the Fathers of the Church. This field of research, expanded in this way, suggests a variety of exegetical ideas and relationship in the considerations of the analyzed authors.
\end{abstract}

Streszczenie. Artykuł przedstawia refleksję starożytnego Kościoła nad tekstem Iz 56,7. Ten Izajaszowy tekst zawierał teologiczne i duchowe znaczenie, dlatego we wczesnej interpretacji chrześcijańskiej służył różnorodnym celom. Zarówno pojęcia, jak i terminologia tej księgi prorockiej stały się integralną częścią chrześcijańskich rozważań na temat kultu, literatury i ikonografii. Doktryna dotycząca „domu modlitwy”, którą opracowano w wczesnym Kościele, zawierała zarówno elementy odrzucenia, jak i nadziei względem narodu żydowskiego. Pewne zaskoczenie stanowi fakt, że tekst Iz 56,7 w gruncie rzeczy nie wywarł decydującego wpływu na Ojców Kościoła. Także w NT analizowany fragment Iz wydaje się nieco pomijany, podobnie jak fragmenty NT, w których jest cytowany (Mt 21,13 i Mk 11,17). Konieczne było zatem uzupełnienie refleksji nad Iz 56,7 szerszym potraktowaniem niektórych wątków eklezjologicznych w refleksji Ojców Kościoła. Ta sfera sugeruje różnorodność egzegetycznych wątków i powiązań w rozważaniach analizowanych autorów.

Słowa kluczowe: Izajasz (księga); egzegeza patrystyczna; komentarze do Iz; Iz 56,7 (interpretacja); świątynia żydowska; miejsce modlitwy; kult chrześcijański.

Keywords: Isaiah (book of); Patristic exegesis; commentaries on Isaiah; Isaiah 56:7 (interpretation); Jewish temple, place of prayer; Christian cult. 
7 he patristic interpretation of the book of Isaiah marks the history of Christianity from the first centuries. The Isaianic texts are more often quoted or alluded to in the NT than in any other part of the OT, with the exception of the Psalms. ${ }^{1}$ This book was a central text for the faith of the nascent Christianity. The early Church found in Isaiah the bases for Christian theology and Christology. Of this rich material we choose a verse of particular historical, typological and ecclesial significance, that is Isa 56:7. The use of this verse after the NT would require a full assessment of the opinions of the Church Fathers and the ancient writers. For the Fathers the impression is that our text was not of any special importance, ${ }^{2}$ because it was lost in the multitude of prophetic testimonies. This study moves to patristic evidence and indicates that Isa 56:7 was an important theological text in the early Church. It played a crucial role in polemics with the Jews and provided a suitable starting point to present the Christian kerygma to the Pagans.

\section{Isaiah's Prophecy and the Early Church}

The book of Isaiah, before systematic comments, was the subject of homilies and catechetical teachings. ${ }^{3}$ The earliest writers (called "Apostolic Fathers") taught and preached with a scriptural mindset. For them "Scripture" meant the Pentateuch, the Prophets (especially the book of Isaiah) and the Sapiential Books. In the Christian tradition the book of Isaiah not only was recognized as canonical, but even called by many patristic authors the "Fifth Gospel". ${ }^{4}$ The Isaianic themes and quotations are present within the NT. ${ }^{5}$

The Christian tradition has attached particular significance to this book as a prediction of the life of Christ. ${ }^{6}$ The Gospel text relates that Christ Himself chose to interpret the prophecy of Isaiah in a synagogue of Nazareth in order to

1 See J.F.A. Sawyer, Isaiah through the Centuries, p. 3.

2 Of course, as far as one could be certain from the published volumes of the Biblia Patristica.

3 See Justin, I Apologia 67.

4 The idea of Isaiah as the "fifth Gospel" goes back to Jerome, Augustine and Isidore of Seville (560-636). See J.F.A. Sawyer, The Fifth Gospel. Isaiah in the History of Christianity.

5 See B.S. Childs, The Struggle to Understand Isaiah as Christian Scripture (passim).

6 In general, the commentaries and homilies re-read the prophetic texts in light of the Christ-event. See R.L. Wilken, In novissimis diebus, pp. 1-19. 
proclaim that it has been fulfilled (see Luke 4:16-21). ${ }^{7}$ The Evangelists, and the Fathers after them, link the story of the life, death and resurrection of Christ with the descriptions of Isaiah. ${ }^{8}$

This vision fuelled by Patristic interpretation and the early Christian writers follows this approach. In doctrinal conflict and development Isaiah's pericopes would play many roles. The Christological interpretation is echoed by early Christians, such as Justin Martyr, Irenaeus of Lyon, and Clement of Alexandria. The text of Isaiah served several purposes, for example the end of sacrifices ${ }^{9}$ or the scriptural authority for bishops. ${ }^{10}$ The passage on the "suffering servant" (Isa 53:1-12) has formed the Church's faith and practice, ${ }^{11}$ already since the time of the Apostolic Fathers. From Isaiah's book the Christians learned about the need for repentance. ${ }^{12}$ Later the Fathers found in it the reasons to encourage humility and forsaking of pride. ${ }^{13}$ To the Jewish world the prophetic text was re-proposed following a messianic interpretation, abundantly present in the NT. ${ }^{14}$ Prophetic texts become irrefutable proof to demonstrate at the same time the dynamism and unity of the divine economy. ${ }^{15}$ The center is made up of a person of Christ who is seen both as a foretaste and as the creator of every prophecy. Justin of Nablus witnesses this. Precisely the liturgical and cat-

7 See N.L. Geisler, Baker Encyclopedia of Christian Apologetics, Grand Rapids 1999, p. 35 .

8 See B.S. Childs, The Struggle to Understand Isaiah, p. 92.

9 Isa 1:11-14 in Epistula Barnabae 2.

10 Isa 60:17 in 1 Clementis $42,5$.

11 Clement of Rome quoted this passage to teach humility from the example of the Lord Jesus Christ (see 1 Clementis 16). Isa 53:1-12 became a key text in many of polemical writings between Christianity and Judaism. Isa 53:3-10 presents the atonement theology connected with the death of Jesus. Origen cited the entire passage in order to explain the prediction of the Savior's death for sinners, a death that had brought benefit and healing (see Contra Celsum II 54-55). It was a prophecy of Christ's death suffered for the salvation of all (see Athanasius of Alexandria, De incarnatione Verbi 34; Gregory of Nazianzus, Epistula 101). For Augustine this pericope sets forth the first, hidden and silent, coming of Christ to be followed by his glorious and manifested advent (In Johannem tractatum IV, 2).

12 Isa 1:16-20 in 1 Clementis 8, 4. For Justin of Nablus the baptism in water brought remission of sins, see I Apologia 61.

13 Isa 2:12; 14:13-16, see Cyprian of Carthage, Epistula 54, 3.

14 See Ignatius of Antioch, Epistula ad Philadelphenos 5, 2; 9, 2; Justin of Nablus, Dialogus cum Tryphone 43, Tertulian, Adversus Judaeos 8. On this subject see M.G. Mara, Profeta, col. 4353.

15 Irenaeus of Lyon, Demonstratio 30. 
echetical context ${ }^{16}$ helped to underline the messianic character of prophetic preaching. ${ }^{17}$ In the works of the Apologists the presence of Isaiah's passages begins to become relevant. ${ }^{18}$ Isaiah presented himself to the pagan world as a witness to the truth of God and His redemption. ${ }^{19}$ Clement of Alexandria identifies the Logos ("our pedagogue, the holy God Jesus") with the "Lord" who spoke to the prophets. ${ }^{20}$ The Christian authors quoted Isaiah to prove the error of Jewish understanding of the biblical texts. ${ }^{21}$

During the Patristic period the main genres of exegetical literature were fairly detailed commentaries, brief scholia and homilies which were often more moralistic rather than strictly theological in character. Origen gave to the Christian community its first commentary on Isaiah. This massive work of thirty books is no longer extant. ${ }^{22}$ However, nine of Origen's homilies on Isaiah were translated into Latin by Jerome. Eusebius of Caesarea, a disciple of Origen, produced the earliest surviving commentary on the prophet. ${ }^{23}$ The Palestinian bishop tried to give a historical interpretation of the prophecies, however it largely depends on Origen's spiritual and allegorical reading. ${ }^{24} \mathrm{He}$ is to be associated with the Latin exegete Victorinus of Petau. ${ }^{25}$

16 An occasion to discover these reflections could be provided by either a liturgical reading in the church or by a feast day in some way connected to the text. Some of these interpretations have been lost and we only learn about their previous existence from references in early Christian writers. In the Church's liturgical use Isaiah's book is read during Advent, Christmas, Lent and Holy Week.

17 For Christians the Jewish messianic age, to which much of Isaiah's material pointed as even the Jews frequently believed, had come to pass in Jesus. According to early Fathers, the promises of Isa 2:2-4 referred to the times of salvation and the universal Church that brings the Gospel to the world.

18 See Justin of Nablus, I Apologia 53; Dialogus cum Tryphone 1-9; Tatianus, Oratio ad Graecos 29; Theophilus of Antioch, Ad Autolycum 1, 14.

19 See Justin of Nablus, I Apologia 30; Irenaeus of Lyon, Adversus haereses IV, 33-34.

20 The theophany in Isa 6, see Clement of Alexandria, Paedagogus 1, 7, 56-60.

21 For example Irenaeus would argue that Isa 7:14 spoke of a virgin conceiving, not only a young woman; see Adversus haereses III 21, 1-4.

22 See B.S. Childs, The struggle to understand Isaiah as Christian Scripture, pp. 69-70.

23 Jerome recalls ten books by Eusebius of Caesarea (but fifteen according to what he says in the prologue to his own commentary).

24 The preface of his commentary makes no mention of his predecessors. It is clear that Eusebius is aided by Origen's commentary to compose his own, as is proved by many exact references to the Alexandrian's work. See B.S. Childs, The struggle to understand Isaiah as Christian Scripture, pp. 79-82.

25 See Jerome, De viris illustribus 74; J. Quasten, A. Di Berardino, Patrology, 3, p. 411. 
Didymus the Blind composed eighteen books on Isa $40-60 .{ }^{26}$ First approach to the text is literal. The Alexandrian author goes immediately to a spiritual and allegorical reading. Among the commentaries on Isaiah are the scholia of Hesychius of Jerusalem ${ }^{27}$ and Procopius of Gaza's catena. ${ }^{28}$ There are six homilies on Isaiah by John Chrysostom where the author demonstrates a strongly moralizing tendency. ${ }^{29}$

Not to be overlooked is the Syriac exegetical tradition linked with the name of Ephrem. ${ }^{30}$ For him the historical nature of the prophetical narratives is not left unnoticed. It rather provides the basis for and is the guarantor of the validity of Ephrem's symbols and analogies. ${ }^{31}$

Theodore of Mopsuestia, perhaps the most consistent of Antiochene exegetes, insists on giving only a grammatical and historical interpretation to the text of Isaiah, and for that reason refuses to supply it with any messianic interpretation. ${ }^{32}$

Jerome was undoubtedly the greatest biblical scholar of the Latin Christianity. He had attempted the explanation of Isaiah, the messianic prophet par excellence, on different occasions. ${ }^{33}$ The eighteen books of his commentary on Isaiah had occupied him for more than two years (408-409). ${ }^{34}$ The commentary, finished in 410, is at once the fullest and the finest of all Jerome's exegetical works. ${ }^{35}$ In this commentary Isaiah was viewed more as an Evangelist than

26 The only part of this prophetic book which he considers original. J. Quasten, A. Di Berardino, Patrology, 3, p. 90.

27 Hesychius produced 2680 glosses on Isaiah. Strongly influenced by Origen in his biblical hermeneutics, he kept close to Alexandrian Christology. See J. Quasten, A. Di Berardino, Patrology, 3, p. 491.

28 These are glosses to separated verses. For a listing of catenae on Isaiah see M. Geerard (ed.), Clavis Patrum Graecorum, IV, Tornhout 1980, C 60-63, pp. 216-217.

29 See B.S. Childs, The struggle to understand Isaiah as Christian Scripture, p. 105-108. There also exists the commentary of Pseudo-Basil of Caesarea on Isaiah 1-16.

30 This author in his authentic works cites or alludes to the Isaianic text about 300 times. See D.D. Bundy, Ephrem's Exegesis of Isaiah, p. 234.

31 Ibid., p. 239.

32 See R. Devreesse, Essai sur Théodore de Mopsueste, p. 93.

33 This is the period of his stay in Constantinople and his translation of Origen's homilies. There is also his own essay on the Seraphim (an explication of Isa 13 and 23), which he included in his commentary.

34 See P. Jay, L'exégèse de saint Jérôme d’après son "Commentaire sur Isaïe" (passim).

35 The opus prophetale of Jerome constituted the essence of his scriptural works. 
a prophet. ${ }^{36}$ In the prologue to his translation of Isaiah, ${ }^{37}$ the Latin Father writes: "He should be called an evangelist rather than a prophet because he describes all the mysteries of Christ and the Church so clearly that you would think he is composing a history of what has already happened rather than prophesying about what is to come." ${ }^{38} \mathrm{He}$ seems beholden for more than one line of interpretation.

After the $4^{\text {th }}$ century commentaries on the book of Isaiah were produced in large number. ${ }^{39}$ In this period the doctrine and praxis were crystallized. In this process too, Isaianic texts provide frequently cited scriptural authority for many arguments. ${ }^{40}$

Cyril of Alexandria wrote line by line commentaries on the prophets. The commentary on Isaiah is a massive work covering the entire book ${ }^{41}$ and the commentary of Theodoret of Cyrus must be added to this work. In keeping with the tenants of Antiochene theology, the Syrian bishop focuses more on the historical sense of the text than Alexandrian writers did. He prefers the literal sense with sober and critical judgment. This does not prevent him from adopting the allegorical and typological interpretation when occasion demands it. ${ }^{42}$ Both authors first interpret the literal meaning of the prophecy and then provide the spiritual explanation. Despite the apparent difference between exegetical methods, both commentaries on Isaiah are very close. A precious, if not exhaustive, list of patristic comments to the prophetic books is found in Cassiodorus. $^{43}$

From these brief notes it is clear that the book of Isaiah has been the creative inspiration for Christianity. Indeed, it is fascinating to discover this biblical book as an inexhaustible resource for rhetoric imaging, theological and spiritual reflections. For the purposes of this article I have collected information found in the Church Fathers, not only in their commentaries on the book of Isaiah, but also in works of various kinds. There are also valuable traditions

36 R.L. Wilken, A. Russell Christman, M.J. Hollerich (eds.), Isaiah interpreted by Christian and Medieval Commentators, p. 1.

37 In the prologue of a homily on the first verses of Isaiah Jerome delivers something of his method of reading the prophets and of the history of Israel.

38 Jerome, Commentarius in Esaiam, prol.

39 See M. Simonetti, Uno sguardo d'insieme, p. 9-44; M.G. Mara, Profeta, 4354.

40 The doctrine of the Trinity is supported by Isa 6:3; 40:12-26.

41 This work fills more than 700 columns in Migne's Patrologia Graeca. See J.D. Cassel, Patristic Interpretation of Isaiah, pp. 154-158.

42 J. Quasten, A. Di Berardino, Patrology, 3, p. 542.

43 See Cassiodorus, De Institutione 3; M.G. Mara, Profeta, 4356. 
drawn from the different sources helping our understanding of interpretative nature of the Isaiah's book since the beginning of Christianity.

\section{A House of Prayer in Jerusalem}

A further problem for the Christian authors was the right interpretation of the sacred texts about Jerusalem and the temple. The quotation of Isa $56: 7^{44}$ played an important role in the narrative of the cleansing of the temple (Matt 21:13; Mark 11:17 ${ }^{45}$; Luke 19:46). ${ }^{46}$

From Josephus we know that the temple was characterized by the synonym "house of prayer", which signified worship. He explicitly identified both prayer and sacrifice at the temple as the worship of God. ${ }^{47}$ For the Gospels Jesus is taking possession of the temple in a sense of taking his right position in his "Father's house".

The Church Fathers usually spiritualized the images that referred to Jerusalem although they did not intend to negate the reality of the holy city. The "earthly" city was projected into a spiritual and transcendent reality. The "heavenly Jerusalem" becomes a locus theologicus and an eschatological symbol. ${ }^{48}$ For this reason Epistle of Barnabas belittles the earthly Temple and recommends the building of a spiritual temple within human hearts. ${ }^{49}$

Justin of Nablus appeals to historical events for validation of Christian interpretations of the fulfillment of prophecies. He quotes Isa 56:750 with reference to accusations raised against the Christians. ${ }^{51}$

44 See S.W. Flynn, „A House of Prayer for All Peoples”, pp. 5-24.

45 See R.L. Wilken, A. Russell Christman, M.J. Hollerich (ed.), Isaiah interpreted by Christian, p. 451.

46 In the version of Matthew and Luke the final words of Isa 56:7 ("for all peoples") are missing. In the late antiquity some Christians had taken Jesus' actions in the temple as an example and had violently attacked the pagan temples. See also John 2:19-22.

47 See Antiquitates Judaicae 8, 108.

48 See M.C. Paczkowski, “The Centrality of Jerusalem," p. 132.

49 According to some scholars, Barnabas discusses hopes of a possible rebuilding of the Temple in Jerusalem by the emperor Nerva: "I will also tell you concerning the temple, how the wretched [Jews], wandering in error, trusted not in God Himself, but in the temple, as being the house of God. For almost after the manner of the Gentiles they worshipped Him in the temple"; Epistula Barnabae 16.

50 See M.C. Paczkowski, “The Centrality of Jerusalem,” p. 117.

51 It is not clear whether the anti-Christian accusations were a historical fact or one has to deal with a literary genre developed on the basis of St. Paul; see G. Visonà (ed.), Giustino. Dialogo con Trifone, p. 126, note 1. 
"You are the cause not only of your own unrighteousness, but in fact of that of all other men ... you displayed great zeal in publishing throughout all the land bitter and dark and unjust things against the only blameless and righteous Light sent by God. For He appeared distasteful to you when He cried among you, 'It is written: My house is the house of prayer; but ye have made it a den of thieves!' (Matt 21:13; Luke 19:46). He overthrew also the tables of the moneychangers in the temple (Matt 21:12)." ${ }^{2}$

The Christians were convinced that Christ had predicted the very destruction of the ancient temple [Matt 24:2]. When it finally occurred, many among the believers were naturally inclined to believe that it had vindicated Christ's prediction and that it had proven the veracity of His words.

The Synoptic passages quoting Isa 56:7 are cited by Irenaeus of Lyon as a witness to the value of the Temple as "God's house".

"It was ... the Truth the One who was speaking and according to truth defended His own House by throwing out the money-changers who sold and bought. He said: 'It is written: My House shall be called a house of prayer, but you have made it a den of thieves' (Matt 21:13; Mark 11:17). For what reason would He have done this to defend the House, had He announced a different God? ... He did not blame the House (of His Father)... but He reprimanded those who used the House inappropriately." 53

Writing against Celsus, the pagan critic of Christianity, Origen affirms that the destruction of Jerusalem and the subsequent exile of the Jewish people, ${ }^{54}$ forty-two years after Jesus' death, was a direct punishment for his crucifixion by the Jews. The cessation of the sacrificial cult was an important element in the divine punishment. ${ }^{55}$ Origen was convinced that the Jews would not be returned to their land, their city and their Temple. ${ }^{56}$ The city where Jesus suffered was destroyed, the Jewish nation was overthrown and salvation transferred to the Church. ${ }^{57}$

52 Dialogus cum Tryphone 17; see also Tertullian, Ad nationess I, 14, 2.

53 Adversus haereses IV, 2, 6. See M.C. Paczkowski, "The Centrality of Jerusalem”, p. 118.

54 The some early Christian authors would read other passages of Isaiah (for example Isa $1: 2-4 ; 6: 9-10$ ) as prophecies of Jewish unbelief in Jesus. See Origen, Contra Celsum II, 8, Tertullian, De oratione 2, Cyprian of Cartago, Testimonia ad Quirinum I, 3.

55 "They had only one holy house of prayer, and one altar of whole burnt-offerings, and one censer for incense, and one high priest of God," Origen, Contra Celsum V 44.

56 See Homiliae in Jeremiam XIX, 14; In Mattheaum comm. series XVIII.

57 Origen, Homiliae in Leviticum X, 1; Comm. in Joannem. X, 24, 138-140; F. Ledegang, Mysterium Ecclesiae, pp. 318-325; 472. 
Cyril of Jerusalem reminded his listeners in the $4^{\text {th }}$ century: "Jerusalem crucified the Christ, but that which now is worships him". ${ }^{58}$ On the other hand, this author is careful to point out the cause of the destruction of the temple, which was on account of Jewish disbelief and not an undermining of the temple's sanctity: "We worship, therefore, the Father of Christ, the Maker of heaven and earth ...; to whose honor the former temple also, opposite us here, was built. For we shall not tolerate the heretics who sever the Old Testament from the New, but we shall believe Christ, who says of the temple: Did you not know that I must be in my Father's house ... Thus he most clearly confessed that the former temple in Jerusalem was his own Father's house". ${ }^{59}$

In the similar context Origen interpreted Isa 56:7 in his commentary on Matthew. While analyzing Matt 21, Origen affirmed that God "recognized His Temple," precisely by quoting this oracle of Isaiah. He also describes the vicissitudes of the Jerusalem Temple, its construction and successive destructions, and concludes as follows: "This place was held as the house of prayer." His main interest lies, however, in the meaning of the expulsion of the sellers from the Temple. In his words, "Our Lord, who gave His action a symbolic and spiritual meaning, in a real way threw out of His Temple both sellers and buyers ... Those who gather there, in (this) House of prayer, must pray". ${ }^{60}$ The destruction of the earthly Jerusalem had opened the way not only to the establishment of the heavenly city ${ }^{61}$ but also to the new cult in every place. ${ }^{62}$

This is the conviction expressed also by the other Christian authors of the time. ${ }^{63}$ For Clement of Alexandria the perfect Christian does not pray only in a special place, but everywhere. ${ }^{64}$ For Tertullian, as regards the place of prayer, the only rule laid down is that of St. Paul: "In every place, he means, which opportunity or even necessity, may have rendered suitable". 65

The use of Isa 56:7, as interpreted in Origen's commentary on Matthew, points to the idea of the "purity of the place of prayer". In fact, Origen says, the

58 Catechesis XIII, 7.

59 Catechesis VII, 7.

60 Origen, In Mattheaum comm. series XVI, 20. See M.C. Paczkowski, Rzeczywistość, symbol i tajemnica, pp. 101-102.

61 See E.D. Hunt, Holy Land Pilgrimage in the Later Roman Empire A.D. 312-460, p. 95, note 64 .

62 Origen, De oratione 31.

63 For the overview see J.F.A. Sawyer, Isaiah through the Centuries, p. 338.

64 See Stromata VII, 7, 35.

65 Tertullian, De oratione 24. 
prayer coming from a "house of prayer" is more pure and acceptable, "as is written: 'My House shall be called a house of prayer' (Isa 56:7)".66

Eusebius of Caesarea introduced the possibility of a reference to the new, physical "house of prayer" for Christian in Jerusalem. He is an important witness of change in Palestine during the reign of Constantine. For the bishop of Caesarea the construction of the Church of the Resurrection by the order of Constantine was manifestly God's inspiration. ${ }^{67}$ The Christian historian indicated: "A house of prayer worthy of the worship of God should be erected near the Savior's tomb on a scale of rich and royal greatness" ${ }^{68}$ Instead of the Judaic temple, the Basilica of the Holy Sepulcher was built. The basilica of Anastasis (Resurrection) is the house of the divine presence, ${ }^{69}$ but also human and historical work. ${ }^{70}$ It is also the fulfillment of ancient prophecies. Cyril of Jerusalem claimed that "the thronging of multitudes of strangers from all parts is not something new in Jerusalem, but this was true in Apostolic times".71

Eusebius of Caesarea explains that Isa 56:7 concerns the return of the exiles from Babylon and the installation of foreign nations in the land of Israel. ${ }^{72}$ In the allegorical sense, as the bishop of Caesarea continues, it concerns the prophets who guide the people into the path of piety as well as the Apostles, Evangelists and disciples of Lord bearing the good news of the faith.

Similar to other ancient Christian authors, St. Jerome was against the Jewish historical interpretation of the Holy City since the OT prophecies were fulfilled with the coming of Christ. Like the early Christian authors, he utilizes the images of Jerusalem to illustrate the spiritual aspects of the new economy. In this theological and spiritual perspective, the ruins of Jewish Jerusalem are the

66 Origen, In Mattheaum Comm. series XVI, 22. For Lactantius God asks "a worship of the mind, a worship both pure and holy?"; Epitome institutionum divinarum LIII; see also De ira Dei XXIV. About Lactantius' interpretation see M.C. Paczkowski, “The Centrality of Jerusalem," p. 120.

67 "This he [= Constantine] did, not on the mere natural impulse of his own mind, but being moved in spirit by the Savior himself" (Vita Constantini III, 25). The resurrection is linked to the idea of Christ as the new sanctuary (Mark 14:57).

68 Eusebius of Caesarea, Vita Constantini III, 25.

69 The sepulcher of Christ is identified with the Saint of the Saints of the ancient temple. See Vita Constantini III, 28.

70 Another historian of the Church, Socrates, links the dedication of the Holy Sepulcher to the inauguration of the "new Jerusalem"; see Historia ecclesiastica I, 17. Egeria establishes an interesting parallelism between the dedication of the Solomonic "house of prayer" and that of the Christian basilica which was its substitute; see Itinerarium Egeriae 48, 2.

71 Cyril of Jerusalem, Catechesis XVII, 16.

72 See M.C. Paczkowski, “The Centrality of Jerusalem,” p. 121. 
proof of the authenticity of Christianity. The fulfillment of the prophetic heralds at the time of Christ by Rome holds an important place in his commentary. Jerome does not risk abandoning the historical explication in favor of dangerous liberties offered by allegory. ${ }^{73}$ Thus, for St. Jerome the Lord's reproach is not only valid in the immediate context of the Gospels but also in the situation of his time in the splendid Christian Jerusalem.

St. Augustine occupies a prominent place among Latin theologians. He interpreted Scripture in both a literal and allegorical fashion. In Cassisiacum he felt the lack of insight into how to read and understand the book of Isaiah. ${ }^{74}$ The bishop of Hippo is not simply "spiritualizing" the reality of "house of prayer". He never forgets that the words of the Scripture speak of physical realities. Jerusalem, as the city of the temple, was the place to which the Jews would go up to meet God, but now the synagogues are intended for this purpose. ${ }^{75}$

Augustine uses the popular model of traditional rhetoric against the Jews. It is deeply grounded in prophetic material, especially Isaiah. "My house will be called a house of prayer for all peoples' (Isa 56:7). But perhaps the Jews will say that the house of God, that is, the synagogue, is open to all. We will not argue the point ... Nothing new is to be seen in what the prophet gives. But if only worthless things can be found, who will say that the prophet is speaking unnecessary? ... To their shame He [God] signals his house is open to all nations for prayer and that since the Jews have abandoned it, he will put others in their place". 76

The Doctor gratiae quotes the salient prophetic text that demonstrates God's universal reach. Even if the Jews were the "Israel of God" before Christ, God abandoned them favoring the Church instead. He emphasizes the vision of the sacrifice offered everywhere: "Not in one place, as was prescribed for [the Jews] in the earthly Jerusalem, but in every place, even in Jerusalem herself". ${ }^{7}$

73 Commentarius in Esaiam V, prol.

74 See Augustine of Hippo, Confessiones IX, 5. Even St. Augustine, for all his greatness, made little advance in interpretation of Isaiah' book.

75 For several centuries Judeo-Christians and even some gentile Christians referred to their houses of prayer as "synagogues". See for example, Ignatius of Antioch, Epistula ad Polycarpum 4, 2; Justin, Dialogus cum Tryphone 63; Epiphanius of Salamis, Adversus haereses (Panarion) XXX, 18.

76 Quaestiones in VT 44. Quoted in: M. Elliott, Isaiah 40-66, p. 195.

77 Adversus Judaeos IX, 13. Augustine is a witness to a practice of the Church's pattern, established by Jesus' exposition of Isaianic text at the beginning of his ministry. It was practiced in the early Church's worship. "The morning ... a great multitude had assembled at the hour of exposition of Scripture, that passage in the Gospel was read in which our Lord said, concerning those sellers who were driven out of the temple, and the tables of the money- 
The bishop of Hippo emphasizes the vision of the Holy City as the house of God made up by the redeemed, who "form one house of God and one city, which is Jerusalem". This clearly results from his exposition: "God's House is also his City; this God's House is the same as the Temple of God. And what says the Apostle (see 2Tim 2:19)? All the faithful are then God's house".78

To discredit the Jewish place of worship, Christian writers tied it up with abandonment and desolation. For Theodoret of Cyrus the remains of the Temple in Jerusalem were the signum of the Christian achievement. ${ }^{79}$

"The God of the universe has shown that He is not only the God of the Jews, but that He is also [the God] of the Gentiles: for since He is the Creator of all men, He cares for all in the same way. You see well why even at the time when He gave the Law, He also told the Jews to love 'the stranger, for you were strangers in the land of Egypt' (Deut 10:19). Here, moreover, by the way of life of those of foreign nations who conduct themselves in accordance with the ancient Law, He opens the door of salvation for all nations. After made these promises to foreigners ..., he predicts to the Jews the final siege of their city to be accomplished by the Romans." 80

Theodoret of Cyrus understood temple as the place of humanity's contact with God. In his commentary he set out to illuminate obscure passages and establish "the proper historical context and its narrative sequence". ${ }^{81}$ Theodoret made some references in the Isaianic text to the impossible rebuilding of the Jerusalem Temple. He referred rather to Christ and to His Church. It is curious that he takes into consideration the hypothesis of the reconstruction of the Jewish temple. ${ }^{82}$ The supposition of the bishop of Cyrus finds no correspondence in the other patristic sources. The paradox that the Christian sanctuaries become subjects of reversal role is crucial to the whole argument of Theodoret. The shrines cease to be exclusively Christian, while the believers from Israel come to pray. This involves a redefinition of the "house of prayer". This would lead to the situation of the existence of Christian sanctuaries alongside the Jewish one, but the parallel existence of the two cults is not possible. This fact would be a reason for continuous disputes and conflicts. However, the author did not

changers which He had overthrown, that the house of His Father had been made a den of thieves instead of a house of prayer." Augustine of Hippo, Epistula 29, 3.

78 Enarrationes in Ps 126, 3. See M.C. Paczkowski, “The Centrality of Jerusalem,” p. 132.

79 See Interpretatio in Ps 121, 3.

80 Theodoret of Cyrus, In Isaiam LVI, 7. The interpretation of Eusebius of Caesarea and Procopius of Gaza is different.

81 B.S. Childs, The Struggle to Understand Isaiah, p. 139.

82 See In Ezechielem 48, 35. 
take into consideration the reality of Palestine in the fifth century. In Hebron the grave sites of the forefathers became a holy place for Jews and Christians. ${ }^{83}$ An eyewitness from the $6^{\text {th }}$ century mentioned that "the Christians came in one side and Jews on the other" ${ }^{84}$

St. Cyril of Alexandria was not only a great theologian, but also an interpreter of the Scriptures. In fact he practiced a profound spiritual and theological exegesis, intended not to be original, as were heretics, but sought to strengthen the true faith of the Church. In his analysis of Isa 56:7, the house and within the walls God "gives a famous place," writes Cyril. This image is interpreted in the allegorical sense. ${ }^{85}$ The metropolitan bishop of Egypt evokes the episode of the purification of the temple to show that Christ was the "One who possessed authority over the temple". ${ }^{86}$

Cassiodorus presented a very general interpretation of Isa 56:7. According to the monk of Vivarium: "You and they have sinned; we are converted, yet they are. Christ as promised, he comes to us and to them. God is not yours alone, as if you did not know that all were born of Adam. It is written that the nations will believe in Christ, as it is said: 'My House shall be called a house of prayer for all peoples' (Isa 56:7) ... He proclaims that each nation ought to be saved through the faith of Christ, that is, by faith in Him" ${ }^{87}$ Here we can see some elements of anti-Jewish controversy.

Following the time the Isaiah's text was a crucial part in Christian antiJewish writings. The same pattern is repeated in Isidore's comments. His De fide Catholica adversus Judaeos, written in the early 7th century, was meant to strengthen the Christian faith and show the ignorance of the Jews through

\footnotetext{
83 This is a good example of how Christian practice influenced Jewish customs.

84 See Itinerarium [rec. altera] 30.

85 Cyril of Alexandria, In Isaiam V, 3 (56:6-8).
}

86 "The Truth, even Christ ... command that ... the temple should manifestly be a house of prayer. For His rebuking the dealers, and driving them from the sacred courts ... We must observe however that another of the holy Evangelists mentions, that not only did the Lord rebuke those dealers by words, but that He also made a scourge of cords, and threatened to inflict stripes upon them; for it was right for those who honored the legal service after the manifestation of the truth, to know, that by retaining the spirit of bondage, and refusing to be set free, they became subject to stripes, and liable to slavish torture. The Savior and Lord, manifests to them His glory for their benefit, in order that they may believe in Him." Cyril of Alexandria, In Lucam sermo 132 (19:45-48; 20:1-8).

87 Expositio in Romanos 3. Quoted in: M. Elliott, Isaiah 40-66, p. 195. 
reference to the OT. ${ }^{88}$ The bishop of Seville found in Isaiah many allusions to the Gospel's narrative.

\section{Isa $56: 7$ in the Ecclesiological Context}

The prophet Isaiah envisaged the conversion of the Gentiles to worshipers of the true God, in which Christian authors saw the pre-announcement of the Church. Justin argues: "[Christ] made [us] a house of prayer and adoration". 89 With the help of the texts of Isaiah this Apologist exposes the question of Israel replacement in the Covenant. ${ }^{90}$

It is understandable that for the Christian authors Isa 56 presents a living portrait of the Church. It is a house of prayer, where people encounter. In it Christian authors saw the pre-announcement of the Church. Whoever enters it is no longer a foreigner, but becomes of the household of the Lord. ${ }^{91}$ The Church is the house of the Lord and his fruitful paradise. There are an everlasting undisturbed joy, and a holy, exalted, spiritual worship (Isa 56:7). Lastly, the Church is the house of mercy and its gates are always open to all. The fulfillment of the Temple as a house of prayer for all nations very well points to the spiritual temple, the Church where God was approached by all people in the name of Jesus. Under the OT economy, only Jews could enter the "house of God". Gentiles were restricted to the "court of the Gentiles", an exterior area of the temple compound. With the rise of the Church the situation had turned upside down: the excluded are the Jews and the elect the pagans who believe in Christ. Only Ebionites even "adore Jerusalem as if it were the house of God".92 By way of contrast, Isaiah indicated that "all nations would flow unto" the house of prayer. Also other Christian groups, connected to the Jewish heritage, disagreed claiming that the destruction of the Temple was not definitive. In general, Christian

88 See J.F.A. Sawyer, The Fifth Gospel, p. 113; S.J. McMichael, Did Isaiah Foretell Jewish Blindness, p. 146.

89 Dialogus cum Tryphone 86.

90 See Dialogus cum Tryphone 22-24; A. Gregerman, Building on the Ruins of the Temple, pp. 47-49.

91 All have living fellowship with God (Isa 56:1). It is the dwelling place of Truth and Justice, as long as we unite with Christ, who justifies the sinners, offers Himself to them as Truth, Justice and Love (Isa 56:1). A feature of this house is sanctification of the freewill. Its gates being open before all, with no exception (Isa 56:2,3).

92 Adversus haereses I, 26, 2. For the Ebionites the land of Israel is the only proper place wherein the people of God may worship. 
thought contested the idea of the Temple as a physical reality. The true Temple was the body of the Lord, and the Church is often represented in this way.

Origen indicates that to the Church "came the teaching about the simple and true worship of God". ${ }^{33}$ The Alexandrian here uses the substitution model, according to which the ancient God's temple and chosen people were replaced by the Christians. This is also evident in the cult: Christian worship does not entail bloody sacrifices, but it is simple and true.

In the house of prayer (i.e. Church), the sacrifice comes out of every heart, nourishes on faith, and keeps truth; enters in innocence and purity, adorned with love. ${ }^{94}$ One can see that the Fathers were able to illustrate the true worship and the eschatological importance of the "heavenly Jerusalem" by means of images connected with Christ, the Church, and the destiny of the believers. ${ }^{95}$ If early commentators read Isaiah with little interest in the original historical setting it was because a new historical context existed. The evangelization of the Gentiles and the misery of the Jewish people ${ }^{96}$ provided a context for Christian interpretation of the prophet. The Christian exegetes did treat the historical settings of the prophecies, sometimes extensively and did use typology. The references to the holy city of Jerusalem are the most apologetically and theologically sensitive parts of Eusebius' works. He deals with the place of the Church in his exegesis of Isaiah. The Palestinian bishop revels that the desire to glorify the triumph of the Church as the fulfillment of prophecy was very important. This fact is seen in the Proof of the Gospe ${ }^{97}$ where the texts cited of Isaiah are not longer set out in continuous sequence. The heavenly Jerusalem is described and interpreted with a catena of NT citations. ${ }^{98}$

The Syriac Didascalia makes a direct connection between the fall of the Jewish Temple and the rise of the Church: "Jerusalem is forsaken .... Your house [the Temple] is left unto you desolate .... God therefore hath left the nation, and hath filled the Church, and had considered her the mount of [His]

93 Origen, Contra Celsum IV, 22.

94 See Tertullian, De oratione 28. For Clement of Alexandria "the true temple of God is the congregation of the saints, and his true image is to be found in the righteous soul, where he is continually enshrined"; Stromata VII, 5, 21.

95 Cyprian proves "that God only admits into the divine and eternal house those among whom prayer is unanimous" (see Acts 1:14); De ecclesiae catholicae unitate 25.

96 After the uprising of Bar Kokhba (132-135) Jerusalem practically became a pagan city.

97 See Demonstratio evangelica VI, 17.

98 A strong eschatological emphasis is present in the exegesis of Isa 62-66. 
habitation ..., and the house of exaltation ... for one only is the Church which is the mountain of the Sanctuary of God". ${ }^{9}$

The object of the references to Isaiah in Ephrem is the Church. ${ }^{100}$ It is comprised of foreigners whom the Lord has chosen who offer up prayers to Him. "The words [of Isaiah] refer to the Church of the Gentiles, as the Lord himself explained to the Jews, and it is written in the Gospel: 'My house shall be called a house of prayer for all nations' ".101 The Latin writer Hilary of Poitiers saw the historical Jerusalem extended beyond the boundaries of its temple, i.e. the house of prayer, and so too does the Church. "The foundation of our house is Christ and the city is built on the mountain, the mountain which is He himself, in whom is sought anyone who has attained to rest." ${ }^{102}$ The perspective is large, but there are elements of Isa 56:7, referring to Christ and his Church.

In Chrysostom's homilies on St. Matthew we see the orator presenting an argumentation against the Jews. He evokes the prophet Isaiah in order to explain whence comes the blinding of the unbelieving Jews.

"This is a heavier charge against the Jews, that when He had done this not once only, but a second time, they continued in their trafficking ... But not even so were they persuaded, but 'were sore displeased', and this while they heard the prophet crying aloud, and the children in a manner beyond their age proclaiming Him. Wherefore also He Himself sets up Isaiah against them as an accuser, saying, 'My house shall be called a house of prayer"' 103

A surprising connection between Jerusalem and the Church is found in St. Jerome's commentary on Mark:

"It is written: 'My house will be called a house of prayer for all peoples' (Isa 56:7) ... God's house has become a den of robbers. This is the house spoken of in Jeremiah: 'Is my inheritance to me a hyena's cave?' (Jer 12:9) ... Jeremiah uses the term 'hyena's cave" [according to the LXX]. ${ }^{104}$ It is useful to know the nature of this animal ... This reasoning applies to the priests of the Jews ... They are only satisfied with the dead people they lead. It is not enough that they do not live in the light themselves, but they make every effort to kill those who live in the light ... If only this sentence referred to the Jews alone, and one could

99 Didascalia 23-24. The Holy Mountain is the eschatological Zion, which incorporates the city and temple.

100 See for example Hymni de nativitate 25: 5.

101 In Isaiam 56,:7.

102 Hilary, Tractatus super Psalmos 14: 5.

103 John Chrysostom, In Matthaeum 67 (21:12.13).

104 John Chrysostom said that "the synagogue is ... a den of robbers and a lodging for wild beasts (quotation of Jer 12:9)"; Adversus Judaeos I, 3. 
not say the same thing of the Christians ... Unfortunately, even today and from different directions the House of God has become a house of business." 105

For St. Jerome the Lord's reproach is not only valid in the immediate context of the Gospels but also in the situation of his time in the splendid Christian Jerusalem. ${ }^{106}$ The Temple had a theological and typological function. The holy mountain and the house of prayer are synonymously interchanged with God's Temple and these are identified with Zion and Jerusalem. In the light of this conviction the Latin exegete states: "For those who believe, salvation is in Mount Zion and Jerusalem". ${ }^{107}$ Isaiah's vision is briefly commented:

"God will lead [the spiritual gifts] to his holy mountain and will cause them to rejoice in his house of prayer. This holy mountain, to which... a great number of Gentiles will stream at the end of the time, ${ }^{108}$ can be understood to signify either the truth teaching that confesses the Trinity, or the Lord himself. The house of prayer is the Church, which is dispersed throughout the whole word. It is not the temple of the Jews, which was restricted to the narrow confines of the land of Judea." 109

In the letter to Rustics, a young monk of Tailless, St Jerome remembered the attitude of the true pastor of the Church:

"Like his Master, he has banished greed out of the temple; and without either scourge of cords or words of chiding he has overthrown the chairs of them that sell doves, that is, the gifts of the Holy Spirit. He has upset the tables of Mammon and has scattered the money of the money-changers; zealous that the house of God may be called a house of prayer and not a den of robbers." 110

This is a good example of how Jerome moved easily between what he understood as the literal, moral and allegorical meanings of a text. ${ }^{111}$ As a whole, Jerome's letters reveal his views on a wide variety of exegetical possibilities and rhetorical topics.

105 Jerome, In Marcum IX (XI, 15-17). See M.C. Paczkowski, “The Centrality of Jerusalem," p. 130.

106 The churches in Jerusalem were as many flags of victory of the new faith. See In Hieremiam IV, 15 (19).

107 Jerome, In Joelem III, 1-2.

108 See Isa 2:2; Mic 4:1.

109 Jerome, Commentarius in Esaiam XV, 22. See R.L. Wilken, A. Russell Christman, M.J. Hollerich (ed.), Isaiah interpreted by Christian, p. 456.

110 Jerome, Epistula 125, 20.

111 For other examples see Ch.A. Hall, Reading Scripture With the Church Fathers, p. 112. 
Ambrose of Milan ${ }^{112}$ clearly indicates that in the Holy Trinity "not only is the operation of the Father, Son, and Holy Spirit everywhere one but also there is one and the same will, calling, and giving of commands, which one may see in the great and saving mystery of the Church. For as the Father called the Gentiles to the Church, saying: 'I will call her My people which was not My people, and her beloved who was not beloved;' and elsewhere: 'My house shall be called a house of prayer for all nations,' so, too, the Lord Jesus said that Paul was chosen by Him to call forth and gather together the Church." 113

In the early Church, it became gradually clear that the Temple and the ancient cult system was transcended by the salvific death and resurrection of Jesus Christ. For the believers, the person of Jesus serves all the functions of the old Temple and cult system. He is the place where the believers meet God, offer prayers and sacrifices perfectly pleasing to God. This point is manifest in the so-called "cleansing of the Temple" by Jesus as found in the Gospel of John. ${ }^{114}$ According to the conviction of Theodoret of Cyrus "the inspired prophets spoke not only for things to come but also gave dogmatic and ethical instruction". ${ }^{115}$

Optatus tried to maintain the unity and reunion of the Church. The tone of his writing was rather mild as he avoided harsh remarks: "The house of God is one; those who have chosen form a party by going outside have made a wall, not a house, because there is no other God to inhabit another house ... . The wall belongs to the house, but is not a house; and your party is like a church, but is not catholic."116

He would indeed appeal to the very universality of the Catholic Church. The end was to rebut the Donatist narrow view of the Church and insistence on being the only true Church.

Despite the ecclesiological preoccupation of St. Augustine, caused in part by the Donatist question, Isa 56:7 has a secondary value for him. The bishop of Hippo still had come to embrace the ideas that the Catholic Church was universal, mother for all and place of true worship of God. Augustine's ecclesial concepts were very similar in content to Ambrose's doctrine. Augustine stated that "in that people [the Jews], plainly, the future Church was much more evidently prefigured." 117 The Lord's words are an essential testimony to the truth

112 He was Augustine's first instructor in the Scriptures and taught allegorical interpretive methodology to him.

113 De Spiritu Sancto ad Gratianum II, 10, 101.

114 See John 2:19-22, also Matt 21:13; Mark 11:17; Luke 19:46.

115 In Isaiam XVIII, 56, 1.

116 De schismate donatistarum III, 10.

117 Augustine, De catechizandis rudibus XIX, 33. 
of Christianity. "With reason the Lord drove from the Temple them to whom He said, 'It is written, My House shall be called the House of prayer, but ye have made it a house of trading'; that is, boasting of your works, seeking no inaction, nor hearing the Scripture speaking against your unrest and trading, 'be ye still, and see that I am the Lord" ".118

The presentation of the cleansing of the temple does not only indicate the past, but also the current situation.

"He nevertheless drove those men out, and suffered not the house of prayer to be made a house of merchandise; how, if $\mathrm{He}$ found drunkards there, what would the Lord do? If the house of God ought not to be made a house of trading, ought it to be made a house of drinking? ... He was scourged by the scourges of the Jews; He is now scourged by the blasphemies of false Christians." 119

For Cyril of Alexandria "home" and "walls" denote prosperity and security ${ }^{120}$ so he describes the Church in this way. ${ }^{121}$ Cyril's vision of the Church was the result of his biblical exegesis. ${ }^{122} \mathrm{He}$ finds in the Scriptures many symbolic images of the Church, including the most important ones, which are the temple and the city of Jerusalem. The texts of the OT have found their true fulfillment in the new way of life in Christ. ${ }^{123}$

Procopius of Gaza instead adheres to the ecclesiological and eschatological sense. The "house of the Father" was for him the heavenly Jerusalem, the Church's pre-announcement.

“' In my Father's house are many mansions' (John 14:2). This is the heavenly city of God, Jerusalem. Instead the 'place [of prayer]' is within its walls. But even in this city, that is on earth, that is the Church. [God] passed his house to all the people. He rejected the Jewish celebrations of those who insulted the pagans, called themselves the part elected by God, the Holy People. [The Lord] gathered everyone in the holy Church, which is indicated by the "holy mountain." "124 This Christian writer evoked in various forms the portrait of the "heavenly Jerusalem," but also the earthly city took first place in his catalogue of cities favored by the emperor Justinian.

118 In Psalmum 71, 16.

119 Augustine of Hippo, In Johannem tractatum X, 4.

120 Cyril of Alexandria, In Isaiam V, 3 (56:6-8).

121 For more descriptions see In Isaiam II, 5; 22, 1-2; III, 1; 28, 1; In Zachariam XL, 8, 4-5; In Psalmum 109, 2; 136, 1.

122 See N. Russell, The Church in the Commentaries of St Cyril of Alexandria, pp. $70-85$.

123 See R. Wilken, Judaism and the Early Christian Mind, p. 75.

124 In Isaiam LVI, 1-11. 
The textual evidence concerning the "house of prayer" no longer matters in confrontations found in Jewish and Christian polemics, but in the customs of some circles of Christians. Later Cassiodorus will demonstrate that the reference to Isa 56 in the scene of the purification of the temple reveals the perfection of Christ. He therefore claims that Jesus "entered the temple of Jerusalem free from sins. Whereas others had entered in house of God for purification." He manifested the virtue of justice, "when He cast the buyers and sellers from the synagogue [sic!], and forbade men to trade in God's temple: 'He says: My House shall be called a house of prayer, but you have made it a den of thieves' (Matt 21:13)."125

In Alexandrian allegory the "house of prayer" is described as a heavenly and glorious one and then also the Church that has spread all over the earth. ${ }^{126}$ Cyril of Alexandria does not deal with Isa 56:7, but focuses more on the previous verses exegesis. ${ }^{127}$ It offers him the opportunity to highlight the trait of continence, characteristic of ascetics. ${ }^{128}$ Leander of Seville ${ }^{129}$ strongly emphasized that it is natural for the human being to become one in prayer and fellowship. Each division is against nature. "It is natural for many to become one, so it is a vice to avoid the sweetness of brotherly love. Let us, then, with our whole hearts be lifted up in joy that Christ has restored to his friendship in a single Church the people who perished from love of strife. In this Church, the harmony of love will again receive them. Of this Church, the prophet foretold, saying: 'My House shall be called a house of prayer for all peoples' (Isa 56:7)."'130

The end of the patristic era did not mean the decline of interest in the book of Isaiah. The same can be said about the Gospel passages that evoked this prophetic text (Matt 21:13; Mark 11:17; Luke 19:46). The Patristic interpreters viewed the OT and the NT as unity that must be interpreted through the God's self-revelation and the incarnation of the Lord.

125 In Psalmum 14, 2.

126 The pope Leo the Great wondered why "the Church of Alexandria, which has always been the 'house of prayer' is not now to be 'a den of robbers'?”, Epistula 156: 4.

127 He sees the reference to those who abstain from marriage and sexual relations, or at least, practice moderation in marriage.

128 In Isaiam LVI, 1-11. Very similar motifs were not missing in Jerome's reflection on Isa 56. "It is a matter of great faith and great virtue to be purest kind of temple of God, in that one dedicates oneself”; Contra Jovinianum I, 12. Quoted in: M. Elliott, Isaiah 40-66, p. 193.

129 He was the brother of the more famous Isidore.

130 Leander of Seville, Homilia de triumpho Ecclesiae. Quoted in: M. Elliott, Isaiah 4066, pp. 194-195. 


\section{Conclusion}

Isa $56: 7$ is the key text analyzed in this study. The Patristic commentaries on Isa 56 reveal the way in which early Christian fathers used the NT texts to develop an understanding of the passage and interpret it to support their own ecclesiastical beliefs. Their reflections also suggest that in writing upon this text, the Christian authors relied on a tradition that was increasingly becoming more established and homogenous. The OT passages, the Gospels and items which remained obscure in it were elucidated by the Christ event. The historical nature of Isaianic texts provides the basis for validity of Fathers' explications.

The quotation of Isa 56:7 is frequently used not only in the biblical commentaries, but also in theological and apologetic works. It is incorporated into numerous accounts of Christian vision of the salvation and defenses of the ecclesial faith. The biblical argumentation supports various aspects of their arguments, but the Isaiah's quotation is frequently isolated and presented without any interpretative comments. However, they are placed in a well-defined context and this suggests a precise reading. For this reason a more cohesive image of the interpretative approach emerges. Moreover, the text of Isaiah appears so clear and obvious that it does not require further explanation. Also the discussion on the reception history of Gospel passages concerning the purification of the temple conveys a compelling portrait of its hermeneutic history. However, one clearly sees that gradually the earthly dimension of the "house of prayer" is projected into a spiritual and transcendent reality.

\section{Bibliography}

\section{Sources}

Ambrosius of Milan, De Spiritu Sancto ad Gratianum, ed. O. Faller, Corpus Scriptorum Ecclesiasticorum Latinorum [= CSEL] 79, Vindobonae 1964, pp. 15-222.

Athanasius of Alexandria, De incarnatione Verbi, ed. Ch. Kannengiesser, Sources Chrétiennes [= SCh] 199, Paris 1973, https://www.ccel.org/ccel/athanasius/ incarnation.i.html [accessed 01.10.2019].

Augustin of Hippo, Adversus Judaeos, ed. M. Falcioni, Nuova Biblioteca Agostiniana $[=\mathrm{NBA}] 12 / 1$, Roma 2003, trans. https://www.roger-pearse.com/weblog/2015/06/11/augustines-treatise-against-the-jews [accessed 01.10.2019].

Augustin of Hippo, Quaestiones in VT, ed. \& it. trans. L. Carrozzi, V. Tarulli, NBA X/3, Roma 1999. 
Augustine of Hippo, Confessiones, ed. M. Pellegrino, C. Carena, NBA 1, Roma 1975, trans. E.B. Pusey, https://www.ccel.org/ccel/augustine/confess [accessed 01.10.2019].

Augustine of Hippo, De catechizandis rudibus, ed. J.B. Bauer, Corpus Christianorum, Series Latina [= CCL] 46, Turnhout 1969.

Augustine of Hippo, Enarrationes in Psalmos, eds. V. Tarulli - T. Mariucci - F. Monteverde, NBA 27-28, Roma 1976-1977, trans. Ph. Schaffm https://www.ccel.org/ ccel/schaff/npnf108. toc.html.

Augustine of Hippo, Epistulae, eds. L. Carrozzi-M. Pellegrino - T Alimonti, NBA 21, Roma 1969.

Augustine of Hippo, In Evangelium Joannis tractatus, eds. O. Campagna, E. Gandolfo, V. Tarulli, F. Monteverde, NBA 24/1-2, Roma 2004, trans. Ph. Schaff, https:// www.ccel.org/ccel/schaff/npnf107.i.html [accessed 02.10.2019].

Basil [Pseudo-], Enarratio in prophetam Isaiam, ed. J.-P. Migne, Patrologiae cursus completus: Series Graeca [= PG] 30, 117-668, ed. P. Trevisan, Corona Patrum Salesiana. Series Graeca 4-5, Rome 1939.

Cassiodorus, De Institutione Divinarum Litterarum, ed. J.P. Migne, Patrologiae cursus completus: Series Latina [= PL] 70, 1105 - 1150.

Cassiodorus, Expositio in Psalmos, ed. M. Adriaen, CCL 97 vol. 2, Turnhout 1958.

Clement of Alexandria, Stromata, eds. C. Mondésert - P.Th. Camelot, SCh 38, Paris 1954; V, ed. A. Le Boulluec - P. Voulet, SCh 278, Paris 1981; VII, ed. A. Le Boulluec, SCh 428, Paris 1997, , trans. Ph. Schaff, http://www.ccel.org/ccel/schaff/ anf02.html [accessed 26.09.2019].

Clement of Alexandria, Paedagogus, ed. O. Stählin, Die griechischen christlichen Schriftsteller der ersten Jahrhunderte [= GCS] 12, Leipzig 1905, trans. Ph. Schaff, http://www.ccel.org/ccel/schaff/anf02.html [accessed 26.09.2019].

Clement of Rome, Epistula ad Corinthios, ed. A. Jaubert, SCh 167, Paris 1971, trans. Ph. Schaff, http://www.ccel.org/ccel/schaff/anf01.html [accessed 24.09.2019].

Constitutiones Apostolorum, eds. A. Baron - H. Pietras, trans. pl. S. Kalinkowski, Źródła Myśli Teologicznej 42, Kraków 2007, pp. 1-293.

Cyprian, Ad Quirinum, ed. R. Weber, CCL 3, Turnholti 1972, pp. 3-179, W. Fletcher, http://www.ccel.org/ccel/schaff/anf05.html [accessed 30.09.2019].

Cyprian, De ecclesiae catholicae unitate, ed. M. Bévenot, CCL 3, Turnholti 1997, pp. 249-268 trans. W. Fletcher, http://www.ccel.org/ccel/schaff/anf05.html [accessed 30.09.2019].

Cyprian, Epistularium, ed. G.F. Diercks, CCL 3 B-D, Turnholti 1972; 1994-1996, trans. R.E. Wallis, http://www.ccel.org/ccel/schaff/anf05.html [accessed 30.09.2019].

Cyril of Alexandria, Commentarii in Joannem, PG 73, pp. 9-756; 74, 9-104.

Cyril of Alexandria, Commentarii in Lucam, ed. R. Payne Smith, S. Cyrilli Alexandriae Archiepiscopi Commentarii in Lucae Evangelium [...], Oxonii 1858.

Cyril of Alexandria, Commentarii in Matthaeum, PG 72, pp. 365-474.

Cyril of Alexandria, Commentarius in Isaiam prophetam, PG 70, 9-1450, trans. R.C. Hill, vols. 1-3, Brookline 2008; 2010.

Cyril of Alexandria, Commentarius in XII prophetas minores, PG 71, 9-1061; 72, 9-364. 
Cyril of Jerusalem, Catecheses, PG 33, 331-1180, trans. E. Hamilton Gifford, http:// www.ccel.org/ccel/schaff/npnf207.ii.xx.html [accessed 01.10.2019].

Didascalia Apostolorum Syriaca, ed. A. Vööbus, Corpus Scriptorum Christianorum Orientalium [= CSCO] 401-402, 407-408, Leuven 1979, trans. A. StewartSykes, Studia traditionis theologiae. Explorations in Early and Medieval Theology 1, Turnhout 2009.

Egeria, Itinerarium, eds. P. Maraval- M.C. Díaz y Díaz, SCh 296, Paris 1982, trans. J. Wilkinson, Oxford 2006 [repr. 3rd ed. 1999].

Ephrem, Commentaria in Isaiam, ed. T.J. Lamy, Sancti Ephraem Syri Hymni et Sermones, 2, Mechelen 1902 .

Ephrem, Hymni de Nativitate (Epiphania), ed. E. Beck, CSCO [Scriptores Syri] 186-187, Leuven 1959.

Epiphanius of Salamis, Panarion (Adversus haereses), ed. K. Holl, GCS 25,31, 37, Leipzig 1915, 1922; 1933, trans. Ph.R. Amidon, New York 1990.

Epistula Barnabae, eds. P. Prigent and R.A. Kraft, SCh 172, Paris 1971, trans. Ph. Schaff, http://www.ccel.org/ccel/schaff/anf01.html [accessed 24.09.2019].

Eusebius of Caesarea, Commentarii in Isaiam, PG 24, 89-526.

Eusebius of Caesarea, Commentarii in Psalmos, PG 23, 441-1221.

Eusebius of Caesarea, Demonstratio evangelica, ed. A. Heikel, GCS 23, Leipzig 1913, trans. W.J. Ferrar, http://www.tertullian.org/fathers /eusebius_de_05_book6. htm [accessed 26.09.2019].

Eusebius of Caesarea, Historia Ecclesiastica, ed. \& trans. K. Lake, Loeb Classical Library 153, vol. 1-2 vols. Cambridge 1926 [repr.2001].

Eusebius of Caesarea, Vita Constantini, ed. F. Winkelmann, GCS 7, Berlin - New York 2008, trans. E. Cushing Richardson, http: //www.newadvent.org/fathers/ 2502. htm [accessed 30.09.2019].

Eusebius, Historia ecclesiastica, Libri V-VII, ed. G. Bardy, SCh 41, Paris 1955.

Gregory of Nazianzus, Epistulae, ed. P. Gallay, GCS 53, Berlin 1969.

Hesychius of Jerusalem, Interpretatio Isaiae, PG 93, 1369-1385.

Hilary of Poitiers, Tractatus super Psalmos, PL 9, 231-907.

Ignatius of Antioch, Epistulae, ed. P.T. Camelot, SCh 10, Paris 1945, trans. Ph. Schaff, http://www.ccel.org/ccel/schaff/anf01.html [accessed 24.09.2019].

Irenaeus of Lyon, Adversus haereses, ed. A. Rousseau - L. Doutreleau - B. Hemmerdinger - Ch. Mercier, SCh 100-101; 152-153; 210-211; 263-264; 293-94, Paris 1965; 1969; 1974; 1979; 1982, transl. R. Grant McQueen, The Early Church Fathers, London 1997.

Irenaeus of Lyon, Demonstratio apostolicae praedicationis, ed. A. Rousseau, SCh 406, Paris 1995.

Jerome, Commentarii in evangelium Matthaei, eds. D. Hurst - M. Adriaen, CCL 77, Turnhout 1969.

Jerome, Commentarii in Prophetas, ed. M. Adriaen, CCL 76; 76 A, Turnhout 1969-1970. Jerome, Commentarius in Esaiam, eds. M. Adriaen, G. Morin, CCL 73; 73A, Turnhout 1963.

Jerome, Contra Jovinianum, PL 32, 211-338. 
Jerome, De viris illustribus, trans. E. Cushing Richardson, https://www.ccel.org/ccel/ schaff/npnf203.iii.html [accessed 02.10.2019].

Jerome, Epistulae, ed. J. Labourt, Collection des Universités de France 1-8, Paris 1950-1958.

Jerome, In Hieremiam prophetam libri VI, ed. S. Reiter, CSEL 59, Vindobonae 1913.

Jerome, In Marcum, PL 30, 589-644.

John Chrysostom, Adversus Judaeos orationes, PG 48, 843-942, ed. \& trans. by P. Harkins Fathers of the Church 68, Washington (D.C.) 1977.

John Chrysostom, Expositiones in Psalmos, PG 55, 39-498.

John Chrysostom, Homiliae in Isaiam, ed. J. Dumortier and A. Liefooghe, SCh 304, Paris 1983.

John Chrysostom, Homiliae in Joannem, PG 59, 23-482, trans. Ph. Schaff, The Nicene and Post-Nicene Fathers 14, Peabody 1994 [repr.],

John Chrysostom, Homiliae in Matthaeum, PG 57, 13-472; 58, 471-794, trans G. Prevost, https://www.ccel.org/ccel/schaff/npnf110.iii.i.html [accessed 02.10.2019].

Josephus Flavius, Antiquitates Judaicae, ed. H.St.J. Thackeray - R. Marcus- L.H. Feldman, The Loeb Classical Library 203; 210; 242; 281; 326; 365;410; 433; 456, Cambridge [Massacchusetts] 1966-1982.

Justinus Martyr, Apologia, ed. Ch. Munier, SCh 507, Paris 2006, trans. D. Minns \& P. Parvis, Oxford Early Christian Texts, Oxford 2009.

Justinus, Dialogus cum Tryphone Judaeo, ed. M. Marcovich, Iustini Martyris Dialogus cum Tryphone (Patristische Texte und Studien 47), Berlin-New York 1997, trans. M. Dods \& G. Reith, The Ante-Nicene Fathers 1, Peabody 1994 [repr.].

Lactantius, De ira Dei, ed. M.F. McDonald, Fathers of the Church 54, Washington 1965. Lactantius, Epitome Divinarum Institutionum, ed. P. Monat, SCh 335, Paris 1987, trans. W. Fletcher, http://www.ccel.org/ccel/schaff/anf07.html [accessed 01.10.2019].

Leander of Seville, Homilia de triumpho Ecclesiae, PL 72, 893-898.

Leo the Great, Epistolae, PL 54, 581-1213, trans. E. Hunt, Fathers of the Church 34, New York 1957.

Optatus of Mileve, De schismate donatistarum adversus Parmenianum, ed. M. Labrousse, SCh 412, Paris 1995.

Origen, Commentarii in Iohannem, ed. C. Blanc, SCh 120, Paris 1966.

Origen, Commentarii in Matthaeum, ed. E. Klostermann - E. Benz, GCS 38, 40, Leipzig 1933, 1935, trans. R.E. Heine, Oxford Early Christian Texts, Oxford 2018.

Origen, Contra Celsum, ed. M. Borret, SCh 132, 136, 147, 150, Paris 1967-1969, trans. F. Crombie, http://www.ccel.org/ccel/schaff/anf04.html [accessed 30.09.2019].

Origen, De oratione, ed. P. Koetschau, GCS 3, Leipzig 1899, p. 297-403, trans. W.A. Curtis, The Ante-Nicene Fathers 4, Peabody 1994 [repr.].

Origen, De principiis, eds. H. Crouzel - M. Simonetti, SCh 252-253; 268-269, Paris 1978; 1980, trans. F. Crombie, http://www.ccel.org/ccel/schaff/anf04.html [accessed 30.09.2019].

Origen, Homiliae in Leviticum, ed. M. Borret, SCh 287, Paris 1981.

Origen, In Ieremiam homiliae, eds. P. Husson \& P. Nautin, SCh 232, Paris 1976.

Origen, In Isaiam homiliae, ed. W. A. Baehrens. GCS 33, Leipzig 1925, pp. 242-289. 
Origen, In Joannem commentaria, ed. C. Blanc, SCh 120, 157; 222; 290, Paris 1966; 1970; 1975; 1982, trans. A. Menzies, The Ante-Nicene Fathers 10, Peabody 1994 [repr.].

Peter Chrysologus, Collectio sermonum, ed. A. Olivar, CCL 24 B, Turnhout 1975.

Procopius of Gaza, Catena in Isaiam, PG 87, 1817-2718.

Socrates Scholasticus, Historia ecclesiastica, ed. P. Maraval, SCh 477, Paris 2004, trans. Ph. Schaff \& H. Wace, https://www.ccel.org/ccel/schaff/npnf202.i.html [accessed 03.10.2019].

Sozomenus, Historia ecclesiastica, PG 67, 844-1629, trans. Ph. Schaff \& H. Wace, https://www.ccel.org/ccel/schaff/npnf202.i.html [accessed 03.10.2019].

Tatian, Oratio ad Graecos, ed. J.C.Th. Otto, Corpus Apologetarum Christianorum saeculi secundi, vol. 6, Wiesbaden 1969, trans. Ph. Schaff, http://www.ccel.org/ccel/ schaff/anf02.html [accessed 23.09.2019].

Tertullian, Ad nationes, ed. J.G.P. Borleffs, CCL 1, Turnholti 1994, p. 9-75, trans. Ph. Schaff, http://www.ccel.org/ccel/schaff/anf03.html [accessed 01.10.2019].

Tertullian, Adversus Judaeos, ed. A Kroymann, CCL 2, Turnhout 1954, pp. 1337-1415, trans. Ph. Schaff, http://www.ccel.org/ccel/schaff/anf03.html [accessed 01.10.2019].

Tertullian, De oratione, ed. G.F. Diercks, CCL 1, Turnholti 1954, pp. 257-274, trans. Ph. Schaff, http://www.ccel.org/ccel/schaff/anf03.html [accessed 02.10.2019].

Theodor of Mopsuestia, Commentaria in prophetas minores, PG 66, 123-632.

Theodoret of Cyrus, Commentaria in Isaiam, ed. J.-N. Guinot, SCh 295; 276; 315, Paris $1980 ; 1982 ; 1984$.

Theodoret of Cyrus, Explanatio in Ezechielem, PG 81, 807 A - 1256 B.

Theodoret of Cyrus, Historia religiosa, ed. P. Canivet et al., SCh 234; 257, Paris 1977; 1979.

Theodoret of Cyrus, Interpretatio in Psalmos, PG 80, 857-1997.

Theophilus of Antioch, Ad Autolycum, eds. G. Bardy, J. Sender, SCh 20, Paris 1948, trans. Ph. Schaff, http://www.ccel.org/ccel/schaff/anf02.html [accessed 24.09.2019].

\section{Studies}

Allenbach J. [et al.], Biblia Patristica. Index des citations et allusions bibliques dans la littérature patristique, vol. 1-6, Paris 1975-1995.

Blenkinsopp J., Opening the Sealed Book. Interpretations of the Book of Isaiah in Late Antiquity, Grand Rapids-Cambridge 2006.

Bundy D.D., "Ephrem's Exegesis of Isaiah" (Studia Patristica 18/4), ed. E.A. Livingstone, Kalamazoo-Leuven 1990, pp. 234-239.

Cassel J.D., "Patristic Interpretation of Isaiah," in: "As Those Who Are Taught" The Interpretation of Isaiah from the LXX to the SBL (Society of Biblical Literature SymS 27), eds. C. M. McGinnis - P. K. Tull, Atlanta 2006, pp. 145-169.

Childs B.S., The Struggle to Understand Isaiah as Christian Scripture, Grand Rapids 2004. 
Devreesse R., Essai sur Théodore de Mopsueste (Studie Testi 141), Vatican 1948.

Elliott M. (ed.), Isaiah 40-66 (Ancient Christian Commentary on Scripture 11), Downers Grove 2007.

Flynn S.W., “'A House of Prayer for All Peoples'. The Unique Place of the Foreigner in the Temple Theology of Trito-Isaiah," Theoforum 37 (2006), pp. 5-24.

Fredriksen P., "Secundum Carnem: History and Israel in the Theology of St. Augustine," in: The limits of ancient Christianity. Essays on late antique thought and culture in honor of R. A. Markus, eds. by W.E. Klingshirn and M. Vessey, Ann Arbor 1999, pp. 26-41.

Geerard M. (ed.), Clavis Patrum Graecorum, IV, Tornhout 1980.

Geisler N.L., Baker Encyclopedia of Christian Apologetics, Grand Rapids 1999.

Gregerman A., Building on the Ruins of the Temple. Apologetics and Polemics in Early Christianity and Rabbinic Judaism (Texts and Studies in Ancient Judaism 165), Tübingen 2016.

Hall Ch.A., Reading Scripture With the Church Fathers, III, Downers Grove 1998.

Hunt E.D., Holy Land Pilgrimage in the Later Roman Empire A.D. 312-460, Oxford 1984.

Jay P., L'exégèse de saint Jérôme d’après son „Commentaire sur Isaïe”, Paris 1985.

Ledegang F., Mysterium Ecclesiae. Images of the Church and Its Members in Origen (Bibliotheca Ephemeridum Theologicarum Lavaniensium 156), Lowanium 2001,

Mara M.G., Profeta - III. Commenti ai libri profetici, Nuovo dizionario patristico e di antichità cristiane, 3, ed. A. di Berardino Genova - Milano 2008, 4353-4357.

McMichael S.J., "Did Isaiah Foretell Jewish Blindness and Suffering for not Accepting Jesus of Nazareth as Messiah? A Medieval Perspective," Biblical Theology Bulletin 26 (1996), pp. 144-151.

Paczkowski M.C., "The Centrality of Jerusalem in the Reflections of the Father of the Church," in: Jerusalem House of Prayer for All Peoples in the Three Monotheistic Religions. Proceedings of a symposium held in Jerusalem, February 17-18, 1997 (SBF Analecta 52), ed. A. Niccacci, Jerusalem 2001, pp. 115-134.

Paczkowski M.C., Rzeczywistość, symbol i tajemnica. Jerozolima w starożytnej literaturze chrześcijańskiej okresu przedchalcedońskiego (Biblioteka Ziemi Świętej-Seria Naukowa), Wrocław 2003, pp. 101-102.

Quasten J., Di Berardino A., Patrology, vol. 3: The Golden Age of Latin Patristic Literature from the Council of Nicea to the Council of Chalcedon, Engl. transl. P. Solari, Rome 1983.

Russell N., "The Church in the Commentaries of St Cyril of Alexandria," International Journal for the Study of the Christian Church 7 (2007), pp. 70-85.

Sawyer J.F.A. The Fifth Gospel. Isaiah in the History of Christianity, Cambridge 1996.

Sawyer J.F.A., Isaiah through the Centuries (Wiley-Blackwell Bible Commentaries Series), Oxford 2018.

Simonetti M., "Uno sguardo d'insieme sull'esegesi patristica di Isaia fra IV e V secolo," Annali di storia dell'esegesi 1 (1984), pp. 9-44. 
Vrame A. C., "Theodoret, Bishop of Kyros as an Exegete of Isaiah 1: A Translation of his Commentary, with an Introduction," Greek Orthodox Theological Review 34/2 (1989), pp. 127-147.

Wilken R., Judaism and the Early Christian Mind. A Study of Cyril of Alexandria's Exegesis and Theology, New Haven-London 1971.

Wilken R.L., "In novissimis diebus. Biblical Promises, Jewish Hopes and Early Christian Exegesis," Journal of Early Christian Studies 1 (1993), pp. 1-19.

Wilken R.L., Russell Christman A., Hollerich M.J. (eds.), Isaiah interpreted by Christian and Medieval Commentators, Grand Rapids 2007. 